\title{
HUBUNGAN POLA MAKAN DENGAN TEKANAN DARAH PADA ORANG DEWASA DI SUMATERA BARAT
}

\author{
Miftah Nur Andamsari ${ }^{1}$, Nur Indrawati Lipoeto ${ }^{2}$, Husnil Kadri ${ }^{3}$
}

\begin{abstract}
Abstrak
Terdapat banyak faktor yang mempengaruhi tekanan darah pada orang dewasa, salah satunya adalah pola makan. Makanan dapat memicu kenaikan atau penurunan tekanan darah. Penelitian ini bertujuan untuk meneliti lebih lanjut tentang hubungan pola makan dengan tekanan darah. Penelitian ini dilakukan pada masyarakat yang bertempat tinggal di Padang Pariaman, Padang, Solok dan Padang Panjang. Penelitian ini merupakan studi cross-sectional dengan jumlah sampel 250 orang. Pengumpulan data responden dilakukan dengan wawancara dan pengukuran tekanan darah. Analisis statistic yang digunakan adalah uji korelasi Spearman. Hasil penelitian ini menunjukkan bahwa $20 \%$ responden menderita hipertensi. Uji korelasi Spearman menunjukkan adanya hubungan antara konsumsi lemak dengan tekanan darah sistolik $(p<0,05)$. Sementara konsumsi lemak dengan tekanan darah diastolik tidak menunjukkan adanya hubungan ( $p>0,05)$. Konsumsi kalori, vitamin $C$ dan kalsium juga tidak menunjukkan hubungan dengan tekanan darah $(p>0,05)$. Kesimpulan dari penelitian ini adalah walaupun tidak terdapat hubungan yang signifikan antara pola makan lemak, kalori, vitamin $\mathrm{C}$ dan kalsium dengan tekanan darah, tapi ada kecenderungan terdapat korelasi yang negatif. Diperlukan penelitian lebih lanjut dengan memperhitungkan faktor resiko lain yang mempengaruhi tekanan darah.
\end{abstract}

Kata kunci: Pola makan, lemak, kalori, vitamin C, kalsium, tekanan darah

\begin{abstract}
There are many factors that have correlation with blood pressure in adult, one of them is food intake. Food can leads the blood pressure to increase or decrease. The objective of the study aims to further investigation the correlation of food intake with the blood pressure. The research was conducted to the people who live in Padang Pariaman, Padang, Solok and Padang Panjang. This research was a cross-sectional study with 250 subject of people. Data collection had done through the interview and measurement of blood. The statistical analysis was Spearman correlation test. The result of this research found that $20 \%$ of respondent was categorized into Hypertension. Spearman correlation test showed that there's a relation between fat intake and systolic blood pressure $(p<0,05)$. While there's no relation between fat intake and diastolic blood pressure $(p>0,05)$. The intake of calorie, vitamine $C$ and calcium showed no relation too with blood pressure $(p>0,05)$. The conclusion of this research is eventhough there was no relationship between intake of fat, calorie, vitamine $C$ and calcium with blood pressure, but they have a negative correlation. There is a need to make same research about this topic with another risk factor that influence blood pressure.
\end{abstract}

Keywords: Food intake, fat, calorie, vitamine C, calcium, blood pressure

Afiliasi Penulis : 1. Mahasiswa Fakultas Kedokteran Universitas Andalas, 2. Bagian IImu Gizi Fakultas Kedokteran Universitas Andalas, 3. Bagian Biokimia Fakultas Kedokteran Universitas Andalas. Korespondensi : Miftah Nur Andamsari. Email: miftahna18@gmail.com Telp: 0817180591 


\section{PENDAHULUAN}

Pada Era Globalisasi saat ini terjadi perubahan gaya hidup dan pola konsumsi makanan dimana-mana. Perubahan tersebut dapat meningkatkan terjadinya hipertensi yang merupakan interaksi antara obesitas dan kerentanan metabolisme endogen. ${ }^{1}$

Hipertensi merupakan penyebab 1 dari 8 kematian yang ada di seluruh dunia. Berdasarkan data WHO pada tahun 2000 , hipertensi telah menjangkiti $26,4 \%$ populasi dunia, dimana sepertiganya berada di negara berkembang dan duapertiganya berada di negara maju. Sementara itu, penderita hipertensi di Asia juga cukup tinggi. Pada tahun 2005 terdapat 67,4 juta orang di Asia yang menderita hipertensi. ${ }^{2}$ Di Indonesia sendiri, Data Riskesdas tahun 2007 menunjukkan prevalensi hipertensi sebesar $31,7 \%$. Sementara itu, prevalensi hipertensi di Sumatera Barat sebesar $31,2 \%{ }^{3}$

The National Cholesterol Education Program (NCEP) menyatakan bahwa terdapat beberapa faktor risiko hipertensi yaitu obesitas abdomen, trigliserida, kadar HDL (High Density Lipoprotein), tekanan darah dan kadar gula darah puasa. ${ }^{1}$ Jauhari tahun 2007 menjelaskan tentang spesifikasi kriteria tersebut, antara lain: lingkar perut pria > $102 \mathrm{~cm}$ dan wanita $>88 \mathrm{~cm}$, hipertrigliseridemia (kadar serum trigliserida > $150 \mathrm{mg} / \mathrm{dl}$ ), kadar HDL $<40 \mathrm{mg} / \mathrm{dL}$ untuk pria, dan < $50 \mathrm{mg} / \mathrm{dL}$ untuk wanita, tekanan darah $>130 \mathrm{mmHg}$ dan kadar glukosa darah puasa $>100 \mathrm{mg} / \mathrm{dL} .{ }^{4}$

Sargowo dkk pada tahun 2011 menunjukkan bahwa terdapat hubungan antara komposisi asupan makan terhadap hipertensi. Dari hasil penelitian tersebut menunjukkan bahwa semakin banyak asupan makan, maka kejadian hipertensi semakin meningkat. Komposisi makanan yang dimaksud adalah asupan karbohidrat, lemak dan total kalori. Komponen yang diukur adalah berat badan (BB), tinggi badan (TB), indeks massa tubuh (IMT), lingkar perut (LP), Tekanan darah sistol, Tekanan darah diastol, total kolesterol, trigliserida, LDL (Low Density Lipoprotein), HDL, GDP (Gula Darah Puasa), Apo B-100, FABP (Fatty Acid Binding Protein) dan Adiponektin. Penelitian ini menunjukkan bahwa pada indikator tersebut, total kolesterol mempunyai nilai tertinggi. Indikator komposisi asupan makanan yang mempunyai nilai paling tinggi adalah total kalori diikuti lemak dan karbohidrat. ${ }^{1}$

Keadaan Hipertrigliserida berkaitan dengan peningkatan resiko penyakit kardiovaskuler. Diketahui bahwa peningkatan kadar trigliserida $1 \mathrm{mmol} / \mathrm{L}$ akan meningkatkan risiko penyakit kardiovaskuler sebesar $32 \%$ pada laki-laki dan $76 \%$ pada wanita. Selain itu, peningkatan kadar trigliserida serum menggambarkan peningkatan mobilisasi asam lemak dari penyimpanan di jaringan adiposa, sehingga menyebabkan akumulasi trigliserida di hati dan jaringan tubuh. Hal ini menyebabkan peningkatan berat badan. ${ }^{5}$

Masih banyak zat lain yang juga berpengaruh terhadap tekanan darah. Kalori, vitamin C, dan kalsium adalah beberapa dari zat tersebut. Kalori merupakan satuan energi bagi tubuh yang berasal dari asupan makan. Apabila kalori yang masuk tubuh lebih banyak dibandingkan kalori yang dikeluarkan dalam bentuk energi, hal ini akan ditimbun dalam lemak tubuh. ${ }^{6}$

Vitamin $\mathrm{C}$ biasanya digunakan untuk suplemen terapi sehari-hari. Vitamin 
C adalah vitamin yang larut dalam air, dapat memutus reaksi rantai peroksidasi oleh radikal bebas dan sebagai donor hidrogen. Jadi, Vitamin C merupakan anti oksidan yang efektif untuk menghentikan reaksi peroksidasi lipid yang dapat diharapkan nantinya memperbaiki stress oksidatif tubuh. ${ }^{7}$

Kalsium memiliki kemampuan menstabilkan membran dan efek vasorelaxing pada sel-sel otot polos. Hal ini mempengaruhi sistem saraf pusat dan perifer simpatik dan memodifikasi homeostasis kalsium, tindakan vaskular, serta tindakan elevasi diinduksi PTH pada kalsium untuk pada gilirannya mengurangi tonus vaskular. Hal ini menyebabkan adanya efek proteksi kalsium terhadap kenaikan tekanan darah dan profil lemak. ${ }^{8}$

Keadaan kelebihan asupan makanan akan membawa pada keadaan obesitas. ${ }^{9}$ Kasus berlebihnya asupan makan penduduk Indonesia terus meningkat dari tahun ke tahun. Data Riskesdas tahun 2007 menunjukkan prevalensi obesitas dan berat badan berlebih pada penduduk usia 15 tahun keatas secara nasional adalah $19,1 \% .{ }^{10}$ Sementara itu, data Riskesdas tahun 2010 meningkat menjadi 21,7\%. Dari pemantauan Dinas Kesehatan Propinsi Sumatera Barat pada tahun 2007 diketahui penderita obesitas dan berat badan berlebih di Sumatera Barat melebihi prevalensi obesitas nasional yaitu 21,9\%. Permasalahan gizi pada orang dewasa cenderung lebih dominan untuk kelebihan berat badan. ${ }^{11}$

Penelitian ini bertujuan untuk mengetahui pola konsumsi per hari dari lemak, kalori, vitamin C dan kalsium serta hubungannya dengan tekanan darah.

\section{METODE}

Penelitian dilakukan di kota $\mathrm{Pa}$ dang pada bulan Januari 2013- Desember 2013. Subjek dalam penelitian sebanyak 250 orang yang diambil dari populasi masyarakat berumur lebih dari 18 tahun yang bertempat tinggal di 4 daerah terpilih di Sumatera Barat, serta memenuhi kriteria inklusi dan tidak memiliki kriteria eksklusi. Pemilihan sampel dilakukan dengan metode multistage random sampling. Instrumen penelitian yang digunakan adalah Kuesioner Demografi, Food Frequent Questionnaire, dan Sphygmomanometer air raksa. Data yang diperoleh diolah secara komputerisasi dan untuk analisis hasil penelitiannya digunakan uji korelasi Spearman dengan tingkat pemaknaan $\mathrm{p}<0,05$.

\section{HASIL DAN PEMBAHASAN}

Responden berumur lebih dari 40 tahun lebih banyak yaitu sebesar $76 \%$. Perempuan lebih banyak dibandingkan laki-laki yaitu sebesar 84\%. Responden berpendidikan tamat SMA paling banyak yaitu sebesar 39,6\% (Tabel 1).

Rata-rata tekanan sistolik responden $128,90 \pm 22,02 \mathrm{mmHg}$, dengan tekanan darah sistolik terendah adalah $90 \mathrm{mmHg}$, dan tertinggi adalah 210 $\mathrm{mmHg}$. Sedangkan rata-rata tekanan diastolik responden $81,18 \pm 11,24 \mathrm{mmHg}$, dengan tekanan darah diastolik terendah adalah $60 \mathrm{mmHg}$, dan tertinggi adalah $120 \mathrm{mmHg}$ (Tabel 2).

Rata-rata konsumsi lemak responden 40,29 \pm 19,78 gram, dengan konsumsi lemak terendah adalah 5,10 gram dan tertinggi adalah 112,60 gram. Konsumsi Kalori rata-rata 1597,48 \pm 493,58 kcal, dengan konsumsi kalori 
terendah adalah 637,90 kcal dan tertinggi adalah $3417,50 \mathrm{kcal}$. Konsumsi Vitamin C responden 57,35 $\pm 29,53 \mathrm{mg}$, dengan konsumsi vitamin $\mathrm{C}$ terendah adalah 5,70 $\mathrm{mg}$, dan tertinggi adalah 199,20 mg. Konsumsi Kalsium rata-rata 201,26 $\pm 105,33 \mathrm{mg}$, dengan konsumsi kalsium terendah adalah 22,20 $\mathrm{mg}$ dan tertinggi adalah 1097,00 mg (Tabel 3).

Tabel 1. Distribusi Responden Berdasarkan Umur, Jenis Kelamin dan Tingkat Pendidikan

\begin{tabular}{lcc}
\hline \multicolumn{1}{c}{ Karakteristik } & Frekuensi & $\%$ \\
\hline Umur & & \\
$<40$ tahun & 60 & 24 \\
$\geq 40$ tahun & 190 & 76 \\
& & \\
Jenis Kelamin & 40 & 16 \\
Laki-laki & 210 & 84 \\
Perempuan & & \\
& & \\
Pendidikan & 30 & 12 \\
Tidak Sekolah & 53 & 21,2 \\
Tamat SD/MI & 33 & 13,2 \\
Tamat SMP & 99 & 39,6 \\
Tamat SMA & 35 & 14 \\
Tamat AK/PT & & \\
\hline
\end{tabular}

Tabel 2. Distribusi Frekuensi Tekanan Darah Responden

\begin{tabular}{ccccccc}
\hline Kelompok & $\mathbf{f}$ & Mean & Median & SD & Min & Max \\
& & & & & & \\
\hline Sistolik & 250 & 128,90 & 120,0 & 22,02 & 90,00 & 210,00 \\
& & & & & & \\
\hline Diastolik & 250 & 81,18 & 80,00 & 11,24 & 60,00 & 120,00
\end{tabular}

Tabel 3. Konsumsi Lemak, Kalori, Vitamin $\mathrm{C}$, dan Kalsium Responden

\begin{tabular}{lcccccc}
\hline Konsumsi & F & Mean & Median & SD & Min & Max \\
\hline $\begin{array}{l}\text { Lemak } \\
\text { (gram) }\end{array}$ & 250 & 40,29 & 37,05 & 19,78 & 5,10 & 112,60 \\
\hline $\begin{array}{l}\text { Kalori } \\
\text { (kcal) }\end{array}$ & 250 & 1597,5 & 1532,1 & 493,6 & 637,9 & 3417,5 \\
$\begin{array}{l}\text { Vitamin C } \\
\text { (mg) }\end{array}$ & 250 & 57,35 & 53,25 & 29,53 & 5,70 & 199,20 \\
\hline $\begin{array}{l}\text { Kalsium } \\
(\mathrm{mg})\end{array}$ & 250 & 201,26 & 186,40 & 105,3 & 22,20 & 1097,0 \\
\hline
\end{tabular}

Hubungan konsumsi lemak dengan tekanan sistolik menunjukkan kekuatan hubungan yang lemah $(r=-$ 0,138 ) dan berpola negatif, artinya semakin tinggi konsumsi lemak maka semakin rendah tekanan sistolik. Hasil uji statistik didapatkan ada hubungan antara konsumsi lemak dengan tekanan darah sistolik $(p=0,029)$. Sementara itu, hubungan konsumsi lemak dengan tekanan diastolik menunjukkan kekuatan hubungan yang lemah $(r=-0,074)$ dan berpola negatif. Hasil uji statistik didapatkan tidak ada hubungan antara konsumsi lemak dengan tekanan darah diastolik ( $p=0,244)$ (Tabel 4).

Hubungan konsumsi kalori dengan tekanan sistolik menunjukkan kekuatan hubungan yang lemah $(r=-$ 0,088 ) dan berpola negatif. Hasil uji statistik didapatkan tidak ada hubungan antara konsumsi kalori dengan tekanan darah sistolik $(p=0,165)$. Sementara itu, hubungan konsumsi kalori dengan tekanan diastolik menunjukkan kekuatan hubungan yang lemah $(r=-0,032)$ dan berpola negatif. Hasil uji statistik didapatkan tidak ada hubungan antara konsumsi kalori dengan tekanan darah diastolik ( $p=0,610)$ (Tabel 4).

Hubungan konsumsi vitamin $\mathrm{C}$ dengan tekanan sistolik menunjukkan kekuatan hubungan yang lemah $(r=$ $0,054)$ dan berpola negatif. Hasil uji statistik didapatkan tidak ada hubungan antara konsumsi vitamin $C$ dengan tekanan darah sistolik $(p=0,398)$. Sementara itu, hubungan konsumsi vitamin $\mathrm{C}$ dengan tekanan diastolik menunjukkan kekuatan hubungan yang lemah $(r=-0,041)$ dan berpola negatif. Hasil uji statistik didapatkan tidak ada hubungan antara konsumsi vitamin $\mathrm{C}$ dengan tekanan darah diastolik $(p=$ 0,514) (Tabel 4).

Hubungan konsumsi kalsium dengan tekanan sistolik menunjukkan kekuatan hubungan yang lemah $(r=-$ 0,083 ) dan berpola negatif. Hasil uji statistik didapatkan tidak ada hubungan antara konsumsi kalsium dengan tekanan darah sistolik $(p=0,189)$. Sementara itu, hubungan konsumsi kalsium dengan tekanan diastolik menunjukkan kekuatan hubungan yang lemah $(r=-$ 
0,053) dan berpola negatif. Hasil uji statistik didapatkan tidak ada hubungan antara konsumsi kalsium dengan tekanan darah diastolik $(p=0,403)$ (Tabel 4).

Tabel 4. Hubungan Konsumsi Lemak, Kalori, Vitamin C, dan Kalsium dengan Tekanan Darah

\begin{tabular}{ccccc}
\hline \multirow{2}{*}{ Konsumsi } & \multicolumn{2}{c}{ Sistolik } & \multicolumn{2}{c}{ Diastolik } \\
\cline { 2 - 5 } & $\mathbf{r}$ & $\mathbf{p}$ & $\mathbf{r}$ & $\mathbf{p}$ \\
\hline Lemak & $-0,138$ & 0,029 & $-0,074$ & 0,244 \\
& & & & \\
\hline Kalori & $-0,088$ & 0,165 & $-0,032$ & 0,610 \\
\hline Vitamin C & $-0,054$ & 0,398 & $-0,041$ & 0,514 \\
\hline Kalsium & $-0,083$ & 0,189 & $-0,053$ & 0,403
\end{tabular}

Terdapat 2 jenis lemak dalam makanan, yaitu lemak jenuh dan lemak tak jenuh. Lemak jenuh inilah yang meningkatkan kadar kolesterol dan trigliserida. Sebaliknya, lemak tak jenuh bermanfaat menurunkan kadar kolesterol dalam darah. ${ }^{12}$

Dalam penelitian sebelumnya, ternyata semakin banyak orang Minang mengkonsumsi kelapa, semakin banyak pula konsumsi ikannya. Konsumsi ikan sangat penting dalam mencegah terjadinya aterosklerosis. Asam lemak omega 3 eicosapentaenoic acid (EPA) dan docosahexaenoic acid (DHA) dari ikan terbukti menurunkan VLDL (very low density lipoprotein), menghambat produksi tromboksan, meningkatkan sintesa prostaksilin, menurunkan viskositas darah dan trombosis sehingga menghalangi pengerasan pembuluh darah yang menjadi resiko terjadinya penyakit kardiovaskuler. ${ }^{13}$

Banyaknya kalori yang masuk akan berkaitan dengan depot jaringan lemak tubuh, berarti bahwa pemasukan kalori yang lebih atau kurang akan mengakibatkan bertambahnya atau berkurangnya jaringan lemak. ${ }^{14}$

Hasil uji statistik didapatkan tidak ada hubungan antara konsumsi vitamin
C dengan tekanan darah diastolik ( $p=$ $0,514)$ (Tabel 4). Hal ini sejalan dengan hasil penelitian Darmasari tahun 2010 yaitu pada uji bivariat didapatkan tidak ada hubungan yang signifikan antara konsumsi vitamin $\mathrm{C}$ dengan tekanan darah sistolik dengan $p=0,154(p>0,05) .{ }^{15}$

Hasil uji statistik didapatkan tidak ada hubungan antara konsumsi kalsium dengan tekanan darah diastolik ( $p=$ 0,403 ) (Tabel 4). Hal ini sejalan dengan hasil penelitian Kiptiyah tahun 2007 yaitu pada uji bivariat didapatkan tidak ada hubungan yang signifikan antara konsumsi kalsium dengan tekanan darah sistolik dengan $p=0,108$ ( $p>0,05)$. Tidak adanya pengaruh kalsium terhadap tekanan darah ini disebabkan karena terlalu rendahnya konsumsi makanan yang kaya akan kalsium. ${ }^{16}$

\section{SIMPULAN}

Rerata pola konsumsi responden per hari untuk Lemak sebesar 40,29 gram, Kalori $1597,48 \mathrm{kcal}$, Vitamin C $57,35 \mathrm{mg}$, dan Kalsium 201,26 mg. Rerata tekanan darah responden untuk tekanan darah sistolik adalah 128,90 $\mathrm{mmHg}$ (SD $\pm 22,02 \mathrm{mmHg}$ ), tekanan darah diastolik adalah $81,18 \mathrm{mmHg}$ (SD $\pm 11,24 \mathrm{mmHg}$ ) dan $20 \%$ responden tergolong ke dalam hipertensi. Terdapat hubungan yang bermakna antara konsumsi lemak dengan tekanan darah sistolik, namun tidak terdapat hubungan dengan tekanan darah diastolik. Tidak terdapat hubungan yang bermakna antara konsumsi kalori dengan tekanan darah. Tidak terdapat hubungan yang bermakna antara konsumsi vitamin $\mathrm{C}$ dengan tekanan darah. Tidak terdapat hubungan yang bermakna antara konsumsi kalsium dengan tekanan darah.

\section{DAFTAR RUJUKAN}

1. Kasiman S. Pengaruh makanan pada sindrom metabolik. Jurnal Kardiologi Indonesia. 2011; 32:24-6.

2. Feryadi R. Hubungan profil lipid dengan kejadian hipertensi pada masyarakat etnik 
Minang Kabau di Kota Padang pada tahun 2012. Universitas Andalas, Padang; 2012.

3. Kementerian Kesehatan RI. Riset Kesehatan Dasar 2007. Jakarta: Kementerian Kesehatan RI; 2007.

4. Hendrayati, Thamrin A. Gambaran asupan asam lemak trans dan lemak total dengan kejadian sindrom metabolik di RS dr. Wahidin Sudirohusodo Makassar. Media Gizi Pangan. 2010; 10(2): 39-43.

5. Trisviana $O$. Pengaruh pemberian margarin terhadap berat badan dan kadar trigliserida serum tikus sprague dawley (skripsi). Universitas Diponegoro, Semarang; 2012.

6. Arisman. Gizi dalam daur kehidupan. Dalam Buku ajar ilmu gizi, Jakarta: EGC Penerbit Buku Kedokteran; 2004.

7. Rahmatini. Pengaruh pemberian vitamin $\mathrm{C}$ terhadap kadar MDA serum pada lansia. Majalah Kedokteran Andalas, 29(2):66-72; 2005.

8. Novitadjama. Makromineral yang mempengaruhi tekanan darah [serial online] 2012 (diunduh 20 April 2013). Tersedia dari: http://novitadjama.wordpress.com.

9. Manampiring AE. Hubungan status gizi dan tekanan darah pada penduduk usia 45 tahun ke atas di Kelurahan Pakowa Kecamatan Wanea Kota Manado (laporan penelitian). Universitas Sam Ratulangi, Manado; 2008.

10. Suryaputra K, Nadhiroh SR. Perbedaan pola makan dan aktivitas fisik antara remaja obesitas dengan non obesitas. Makara Kesehatan. 2012; 16(1): 45-50.
11. Kementerian Kesehatan RI. Riset Kesehatan Dasar 2010. Jakarta: Kementerian Kesehatan Rl; 2010. http://www.litbang.depkes.go.id/ sites/download/buku_laporan/lapnas_riskes das2010/Laporan_riskesdas_2010.pdf (diunduh 25 desember 2013)

12. Agustini Z, Wahyuni ES, Nila F. Hubungan asupan lemak (lemak jenuh, tak jenuh, kolesterol) dan natrium terhadap tekanan darah pada pasien hipertensi di Poli Penyakit Dalam RSP Batu (jurnal). Universitas Brawijaya, Malang; 2013.

13. Liputo NI. Masakan Minang dan resiko penyakit kardiovaskuler. Disampaikan pada 'Temu Ilmiah Menjelang Pulang Basamo' Lustrum ke X FK Unand, Jakarta; 2005.

14. Markum. IImu kesehatan Anak, Jakarta: FKUI; 1991.

15. Darmasari E. Hubungan konsumsi antioksidan dengan tekanan darah pada masyarakat di Sumatera Barat (tesis). Universitas Andalas, Padang; 2010.

16. Kiptiyah R. Hubungan asupan natrium, kalium, kalsium dan magnesium dengan tekanan darah sistolik lansia wanita (studi di panti wredha Pucang Gading, Semarang, tahun 2007) (skripsi). Semarang; 2007. 